\title{
Disposal of municipal solid waste with in situ termireactors: proof-of-concept
}

\author{
SA Abbasi ${ }^{*}$ and S Gajalakshmi
}

\begin{abstract}
Background: Termites, which are among the nature's most effective scavengers and earthmovers, are distinguished by their ability to process lignin. In this report, arguably the first of its type, we present studies in which termites have been utilized for solid waste disposal. Twenty-five different types of solid wastes were positioned by us in in situ termireactors, at different locations and at varying distances away from the mounds of different termite species. The rate of consumption of the substrates was monitored as a function of time.

Results: The results reveal that substrates such as cotton waste, coconut shells, and torn jute bags, which resist composting, vermicomposting, or anaerobic digestion, are successfully decomposed by termites. Different termite species were able to bypass some substrates kept nearer their mounds and go to some other substrates kept farther away, showing their preference for different wastes as well as their ability to discern one waste type from the other.
\end{abstract}

Conclusions: The work provides proof-of-concept that termites can be used for the assimilative disposal of MSW.

Keywords: Termites; MSW; Termigradation; Termireactors; Anaerobic digestion; Vermicomposting

\section{Background}

Anthropogenic processes for the treatment of biodegradable solid waste revolve round the use of aerobic, anaerobic, and facultative bacteria [1,2]. Be it a sanitary landfill, a composting system, a solid-feed anaerobic digester, or a bioprocess of some other kind, bacterial digestion has been central to the treatment of biodegradable solid wastes [3-7]. The only exception to this general rule has been vermicomposting wherein the action of bacteria and enzymes on solid waste is mediated (and controlled) by earthworms. The animal ingests solid waste along with soil and deposits the digested material in the form of seed-like vermicast. During the passage through the worm gut, the feed is acted upon by the gut microflora and gets significantly stabilized. The resulting vermicast is a good soil conditioner and fertiliser [8-13].

But neither vermicomposting nor direct bacterial action during any of the economically viable solid waste degradation processes can handle lignin $([4,5] \mathrm{a}, \mathrm{b})$. 'Hard' biowastes such as coconut shells and woody biomass also defy swift biodegradation.

\footnotetext{
* Correspondence: abbasi.cpee@gmail.com

Center for Pollution Control and Environmental Engineering, Pondicherry University, R.Venkataraman Nagar, Kalapet, Puducherry 605 014, India
}

In an attempt to find a quicker and more widely applicable way to dispose large volumes of biowaste, especially the type of biowaste - mentioned above - which resists treatment methods currently in general use, we have begun exploring a new frontier: termigradation. This is one of the first reports, perhaps the first ever, on the use of termites in disposing solid waste. Termites are among the nature's most powerful scavengers and earth movers, alongside earthworms and ants [14-16]. But unlike the other two, termites harbour in their midst microflora which have the special ability not possessed by other animals: ability to digest lignin [17]. In case of lower termites, ligneous material is masticated and ingested which is then digested by microflora present in certain species of protozoa living symbiotically in the termite gut $[18,19]$. In case of higher termites, the microflora capable of digesting lignin is present directly in the animal gut $[18,19]$.

Other characteristics of termites which make them potential candidates for bioprocessing of solid waste are [20]: a) their voracious appetite; b) their ability to consume a wide variety of wastes; c) diversity of their habitat preference which makes it possible to always find one or other species suitable for a given geo-climatic situation [21-23]; d) their very fast rate of population growth; and e) good quality of protein represented by 
termite bodies, making them ideal as poultry feed or source of chemicals such as biofuel $[24,20]$.

But any endeavour to develop bioreactors based on termites has to overcome a unique challenge. It lies in the fact that termites are 'eu-social' animals with welldefined and uncompromising social hierarchy [25]. Unlike earthworms, of which every single individual has the potential to reproduce sexually while it is feeding upon the waste in a bioreactor, the worker termites cannot breed. It is, therefore, not possible to inoculate a pile of waste with worker termites and expect that the workers would feed and breed till the entire waste is consumed. For any termireactor to function sustainably, it has to be ensured that the workers keep coming from termite nests where the workers are being born and reared continuously (along with, of course, other termites of higher caste viz soldiers). To achieve this objective, we have explored the concept of in situ termireactor wherein chambers containing the waste are placed near preexisting termite mounds. The chambers have sufficient openings to allow access to termites but are otherwise closed from all sides.

\section{Methods}

\section{Substrate}

Different constituents of municipal solid waste (MSW) were assessed including cardboard, paper waste, pieces of jute and cotton, coconut shells, leaf litter, etc. Paper waste, tattered jute bags, pieces of cardboard, and coconut shells were collected from the piles of municipal solid waste generated at the residential quarters of the Pondicherry University campus. Scraps and pieces of wood were obtained from a saw mill. Fresh cow dung and paddy straw were collected from a cattle farm. Tissue paper rolls made out of recycled paper, and cosmetic grade cotton were purchased from the market.

Leaf litter from 13 different types of trees: asoka (Polyalthia longifolia), pencil tree (Acacia auriculiformis), coconut (Cocos nucifera), cashew (Anacardium occidentale), palm (Borassus flabellifer), guava (Psidium guajava), mango (Mangifera indica), teak (Tectona grandis), banyan (Ficus benghalensis), jack (Artocarpus heterophyllus), tamarind (Tamarindus indica), peepal (Ficus religiosa), and pungam (Pongamia pinnata) was assayed in the experiments. The litter was collected from below the tree canopies. After removing the debris and leaves of other species, dry weight of the leaf litter of each tree species was estimated by oven drying weighed samples at $105^{\circ} \mathrm{C}$ to constant weight.

\section{In situ termireactors}

To assess the consumption of different MSW constituents by termites, each constituent was kept in an in situ termireactor of rectangular shape, made up from 3-mm-thick aluminium sheets. Each of the termireactors was placed in a shallow pit $(45 \times 30 \times 2 \mathrm{~cm})$, dug by us in the ground, at a measured distance away from the termite mound. All termireactors had holes of $1 \mathrm{~cm}$ diameter at the sides and the bottom to allow termites to access the waste.

\section{Assessment of termigradation}

The termireactors were located in such a way that the minimum distance between any two reactors as well as the distance between the reactors and the mound was $30 \mathrm{~cm}$. This setup helped to spatially demarcate one substrate from the other as well as to keep the distance travelled by the termites from the nest to the pit almost equal. In each of the termireactors, $100 \mathrm{~g}$ (fresh weight) of the substrate was placed. The equivalent dry weight of each substrate was concurrently determined by ovendrying a known mass to a constant weight at $105^{\circ} \mathrm{C}$. The substrates were moistened with tap water, to the extent that the contents become damp but not soggy. To protect the substrates from rainfall, direct sunlight, and disturbance by other animals, the pits were covered with polythene sheets reinforced with aluminium mesh. The covers were removed once in 10 days, to assess the termite action, to maintain adequate moisture content and to see if any interference of other soil macro fauna like ants, was occurring. After 60 days, the substrate remaining unconsumed by the termites was carefully removed from the termireactors and air-dried. Care was taken to brush off any soil particles adhering to the surface of the residue. Then, the residue was oven dried at $105^{\circ} \mathrm{C}$ to constant weight.

Experiments were also conduced to see whether the termites go to the nearest available substrate or go further in search of more favoured substrate if the one available at shorter distance is less agreeable. Termireactors of the type identical to ones described above were set up at varying distances away from the mounds. The substrates were kept in the termireactors in such a way that different substrates were located at different distances from the mound. The first substrate was kept $1 \mathrm{ft}$ away from the mound, the second $2 \mathrm{ft}$ away and the third $3 \mathrm{ft}$ away. In all, 14 different substrates were placed at distances progressively away from the mound. The farthest a substrate was placed was $14 \mathrm{ft}$ away from the mound.

\section{Results and discussion}

The 'termigradability' of 25 different substrates studied by us, in terms of fraction of the substrate consumed (dry weight basis), is presented in Figure 1.

The results (Figure 2) show that not only ligninous material but other tough-to-degrade substrates like cardboard were also consumed by termites (up to $41.65 \%$ ). Moreover, substrates such as cotton waste and torn jute 


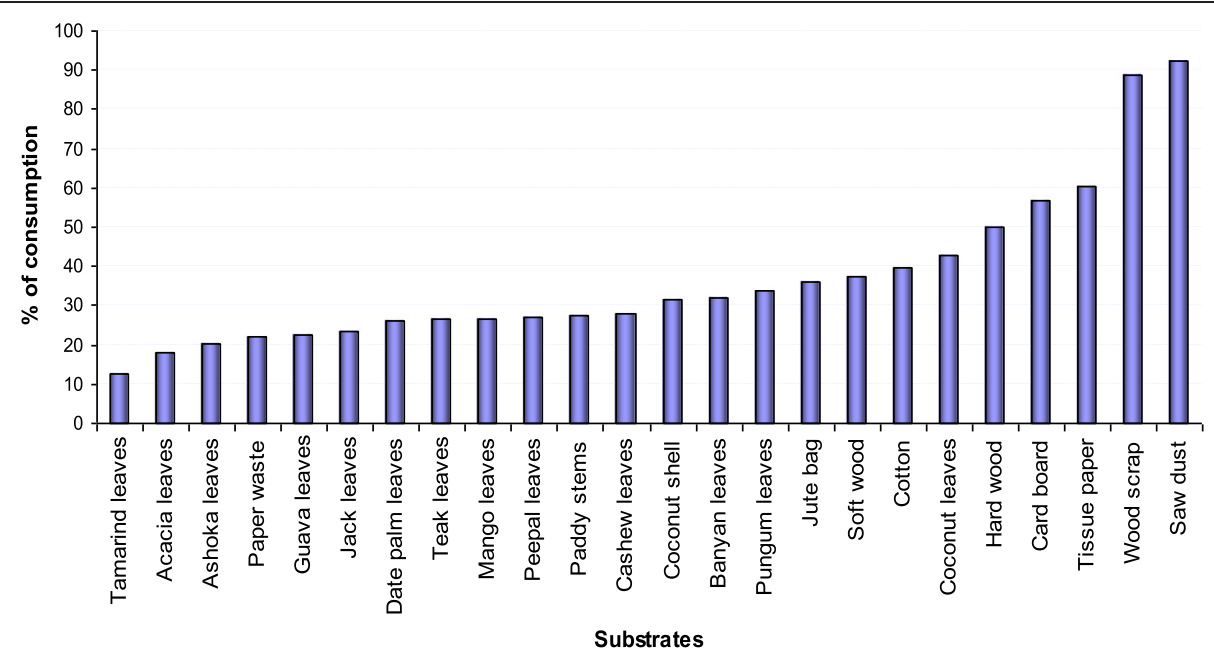

Figure 1 Average consumption of quadruplicate samples of the substrates by the termites.

bags, which resist bioprocessing during composting or vermicomposting, were also successfully consumed by termites. The studies thus confirm the potential of termites in processing ligninous and other 'hard' substances which defy composting, vermicomposting, and other forms of bacterial action in conventional solid waste management systems. Of special significance is our finding that pernicious weeds, like ipomoea, can be termidegraded. This is a finding of high promise. It is also significant that termites were able to degrade about $40 \%$ of cardboard within 60 days because otherwise cardboard is resistant to biodegradation [26]. Indeed, due to their resistance to biodegradation, cardboard pieces are often used as bulking agents in composting/vermicomposting systems [27].

Several species of white rot fungi (WRF) notably Phanerochaete chrysosporium, Ceriporiopsis subvermispora, Pycnoporus cinnabarinus, Fuscoporia ferrea, Trametes pubescens, T. multicolor, Coriolus versicolor, and Pleurotus sajar-caju are known to degrade lignin $[28,29]$. Attempts to utilize this ability in treating ligninous wastes have been made since long, with increasing intensity since early 1970 s [30-34]; But the rate at which WRF acts is very very slow

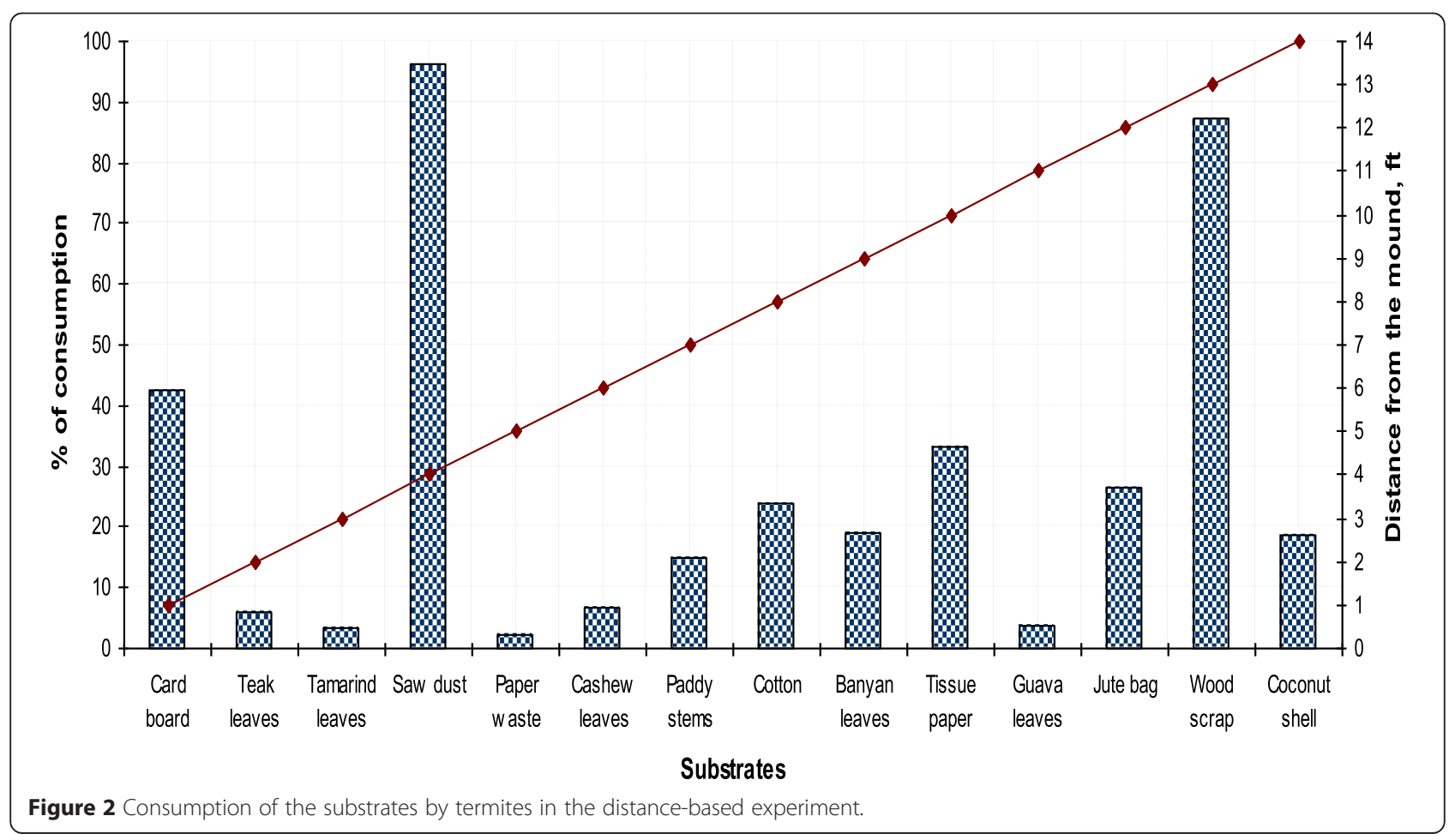


$[35,32]$ and, due to this, not a single process has been developed till now which makes use of WRF in degrading lignin on a commercial scale [36]. The present work suggests that termites may be able to process lignin at rates that are faster than possible with WRF but further work is needed to get a confirmation of this indication.

Figure 2, which indicates how far will termites venture out from some substrates in preference to others, indicates that the two substrates most voraciously consumed - sawdust and wood scrap (Figure 1) - are also the ones to which termites will go even if they lie a little farther away than the other substrates.

The preceding discussion is based on the extent of substrate consumed and does not give any information on the quantity or the characteristics of termicast. The reason is that in contrast to vermicomposting - which happens to be the only pre-existing bioprocess used in pollution control that is mediated by a multi-cellular animal $-50 \%$ to $60 \%$ of the substrate is converted to vermicast, termites produce no 'termicast'. This is because termites are extremely efficient utilizers of food due to the staggering diversity of the microflora present in their gut [37]. Up to $93 \%$ of the ingested food is assimilated by termites [38,39]. Very little of what termites ingest is excreted; the excreta are made up of organomineral aggregates which are carried away by the worker termites to line the termite nests $[40,16]$. As a result, no 'termicast' is obtained in the termireactors and the extent of substrate consumption is quantified on the basis of what is left off [10].

Moreover, whereas in a vermireactor, we can control the number of the feeders (adult earthworm) and can work out per capita vermicast production, per unit time, such assessments are not possible in termite-based systems - for reasons that have been explained in the paper (last para of the 'Background' section). Hence, the rate of disposal of the waste is assessed on the basis of the fraction consumed rather than on the basis of cast produced (as is done in vermireactors).

In summary, there is really no way to precisely determine how much of the ingested lignin is decomposed in the 'termireactors' but given the fact that termites leave little residue, it can be easily surmised that the bulk of the ligneous material that termites eat is converted to termite zoomass. Also, evidence of termite action is very stark in all these reactors while no other organisms are seen who could have contributed to the consumption.

\section{Conclusions}

The studies provide a fairly convincing 'proof-of-concept', and we are now aiming to translate these findings into practicable waste treatment systems. At present, attempts are underway to develop captive colonies of some of the termite species within the confines of laboratories so that they can be used in a controlled fashion to treat specific components, as well as unsorted forms, of municipal solid waste.

We hope that further work on this new frontier would lead to new technology which could have great potential in handling 'difficult' organic solid waste - including that which is generated in several industries.

\section{Competing interests}

The authors declare that they have no competing interests.

\section{Authors' contributions}

The idea of using termites in treating ligninous waste was conceived and developed by SAA. It was tested and refined with the assistance of SG.

\section{Acknowledgements}

The authors would thank the Department of Biotechnology, Government of India for support in the form of R\&D project. We also thank our research students, Mr. Ramachander, Mr. Anbalagan, and Mr. Santhosh: especially Dr. P. Sankar Ganesh and Ms. Gurjeet Kaur for their help from time to time.

Received: 26 June 2014 Accepted: 21 April 2015

Published online: 27 May 2015

\section{References}

1. Kreith F, Tchobanoglous G (2002) Handbook of solid waste management, 2nd edn. McGraw-Hill Professional, USA

2. Dhamija U (2006) Sustainable solid waste management: issues policies and structures. Academic Foundation, New Delhi, 264 pages

3. Gajalakshmi S, Abbasi SA (2008) Solid waste management by composting: state of the art. Crit Rev Environ Sci Technol 38:311-400

4. Abbasi T, Abbasi SA (2010) Biomass energy and the environmental impacts associated with its production and utilization. Renew Sust Energ Rev 14:919-937

5. Abbasi T, Abbasi SA (2010) Production of clean energy by anaerobic digestion of phytomass - new prospects for a global warming amelioration technology. Renew Sust Energ Rev 14:1653-1659

6. Abbasi T, Tauseef SM, Abbasi SA (2012) Anaerobic digestion for global warming control and energy generation: an overview. Renew Sust Energ Rev 16:3228-3242

7. Ramasamy EV, Abbasi SA (2001) Solid waste management with earthworms. Discovery Publishing House, New Delhi

8. Abbasi T, Gajalakshmi S, Abbasi SA (2009) Towards modeling and design of vermicomposting systems: mechanisms of composting/vermicomposting and their implications. Indian J Biotechnol 8:177-182

9. Abbasi SA, Nayeem-Shah M, Abbasi T (2014) Vermicomposting of phytomass: limitations of the past approaches and the promise of the clean and efficient high-rate vermicomposting technology. Journal of Cleaner Production. doi:10.1186/s40643-014-0026-4

10. Karthikeyan M, Gajalakshmi S, Abbasi SA (2014a) Effect of storage on the properties of vermicompost generated from paper waste: with focus on pre-drying and extent of sealing. Int J Energy Environ Eng 5(135):1-11

11. Karthikeyan M, Hussain N, Gajalakshmi S, Abbasi SA (2014) Effect of vermicast generation form an allelopathic weed lantana (Lantana camara) on seed germination, plant growth, and yield of cluster bean (Cyamopsis tetragonoloba). Environ Sci Pollut Res. doi:10.1007/s11356-014-3103-5

12. Karthikeyan M, Gajalakshmi S, Abbasi SA (2014) Ingestion of sand and soil by phytophagous earthworm Eudrilus eugeniae: a finding of relevance to earthworm ecology as well as vermitechnology. Arch Agron Soil Sci 60(12):1795-1804

13. Ganeshkumar T, Premalatha M, Gajalakshmi S, Abbasi SA (2014) A new process for the rapid and direct vermicomposting of the aquatic weed salvinia (Salvinia molesta). Bioresources Bioprocessing 1:26

14. Abe T, Bignell DE, Higashi M (2000) Termites: evolution. Symbiosis, Ecology, Kluwer Academic Publishers, Dordrecht, Sociality

15. Konig H, Varma A (2006) Intestinal microorganisms of termites and other invertebrates. Springer-Verlag Berlin, Heidelberg

16. Bignell DE, Roisin Y, Lo N (2011) Biology of termites: a modern synthesis. Springer, London 
17. Ohkuma M (2003) Termite symbiotic systems: efficient bio-recycling of lignocelluloses. Appl Microbiol Biotechnol 61:1-9

18. Butler JHA, Buckerfield JC (1979) Digestion of lignin by termites. Soil Biol Biochem 11:507-513

19. Breznak JA, Brune A (1994) Role of microorganisms in the digestion of lignocellulose by termites. Annu Rev Entomol 39:453-487

20. Premalatha M, Tauseef SM, Abbasi T, Abbasi SA (2013) A website to showcase the human-friendly aspects of termites. Curr Sci 105(11):1459-1460

21. Harit A, Gajalakshmi S, Abbasi SA (2011) Species composition and duration of termite swarms at a wooded location in Puducherry- II: The pattern in the year 2010, ECOCORPS-2011, National Seminar on Environmental Challenges in conservation of Resources of 'ONE' Planet for Sustainable Development. Department of Environmental Sciences, Bishop Heber College, Tiruchirappalli, India

22. Harit AK, Gajalakshmi S, Abbasi SA (2013) Swarming of the termite Coptotermes gestroi in north-eastern Puducherry. Zool Ecol 24:62-69

23. Anantharaju T, Kaur G, Gajalakshmi S, Abbasi SA (2014) Sampling and identification of termites in Northeastern Puducherry. J Entomol Zool Studies 2(3):225-230

24. Premalatha M, Abbasi T, Abbasi T, Abbasi SA (2011) Energy-efficient food production to reduce global warming and ecodegradation: the use of edible insects. Renew Sust Energ Rev 15:4357-4360

25. Krishna and Weesner (1969) Biology of termites. Vol. 1. Academic Press, New York

26. Ruiz M, Pastor K, Acevedo A (2013) Biodegradability of disposable products in a vermicomposting system. Informacion Tecnologica 24(2):47-56

27. Dominguez J, Edwards CA, Webster M (2000) Vermicomposting of sewage sludge: effect of bulking materials on the growth and reproduction of the earthworm Eisenia andrei. Pedobiologia 44(1):24-32

28. Giles RL, Zackeru JC, Elliott GD, Parrow MW (2012) Fungal growth necessary but not sufficient for effective biopulping of wood for lignocellulosic ethanol applications. International Biodeterioration \& Biodegradation, 67, pp 1-7.

29. Hatakka A, Hammel KE (2012) Fungal bioremediation of lignocelluloses. In: Industrial applications, 2nd Edition, The Mycota X; M.Hofrichter (ed.), Springer-Verlag Berlin Heidelberg, 319-340.

30. Abbasi SA (1985) Occurrence, toxicity and treatment of lignin in pulp and paper effluents-state of the art. J S Afr Inst Civ Eng 65:1-8

31. Abbasi SA, Bhatia KKS, Nandeshwar MD, Nipaney PC (1991) Environmental impact of pulpmill effluents on an estuary on the Malabar coast. J Inst Publ Health Eng 4:28-37

32. Li P, Lee C, Lin J (2012) Using biological process to destroy lignocellulosic structure for energy conversion. Adv Mater Res 343-344:273-277

33. Narayanaswamy N, Dheeran P, Verma S and Kumar S (2013) Biological pretreatment of lignocellulosic biomass for enzymatic saccharification. In: Fang Z (Ed.) Pretreatment Techniques for Biofuels and Biorefineries. Green Energy and Technology. Springer-Verlag Berlin Heidelberg, pp. 3-34

34. Malakani M, Khademieslam H, Hosseinihashemi SH, Zeninaly F (2014) Influence of fungal decay on chemi-mechanical properties of beech wood (Fagus orientalis). Cellul Chem Technol 48(1-2):97-103

35. Gupta R, Mehta G, Khasa YP, Kuhad RC (2011) Fungal delignification of lignocellulosic biomass improves the saccharification of cellulosics. Biodegradation 22(4):797-804

36. Kaur G (2014) Sampling and identification of termites in Northeastern Puducherry and exploration of their use in treating ligninous solid waste, $\mathrm{PhD}$ thesis, Pondicherry University

37. Warnecke $F$ et al (2007) Metagenomic and functional analysis of hindgut microbiota of a wood feeding higher termite. Nature 450(7169):560-565

38. Wood TG (1978) Food and feeding habits of termites. In: Brian MV (ed) Production ecology of ants and termites. Cambridge University Press, London

39. Lavelle P (1997) Faunal activities and soil processes: adaptivestrategies that determine ecosystem function. Adv Ecol Res 27:93-132

40. Grube S (2001) Soil modification by the harvester termite Hodotermes mossambicus (Isoptera: Hodotermitidae) in a semi-arid savanna glass land of Namibia. Sociobiology 37:757-767

\section{Submit your manuscript to a SpringerOpen ${ }^{\odot}$ journal and benefit from:}

- Convenient online submission

- Rigorous peer review

- Immediate publication on acceptance

- Open access: articles freely available online

- High visibility within the field

- Retaining the copyright to your article

Submit your next manuscript at $\gg$ springeropen.com 